\title{
Основні принципи фізичної терапії в умовах відділення анестезіології та інтенсивної терапії
}

\author{
УДК 616-085:615.8
}

\author{
Ю. І. Ярош, М. Я. Романішин
}

Національний університет фізичного виховання і спорту України, Київ, Україна

Резюме. На сьогодні актуальним є вивчення застосування фізичної терапії в умовах відділення анестезіології та інтенсивної терапії. Мета. Виділити основні порушення стану пацієнтів в умовах відділення анастезіології та інтенсивної терапії; визначити ефективні методи впливу щодо відновлення функціонального стану хворих; сформулювати принципи фізичної терапії, які визначають методи впливу на стан пацієнта відносно його порушень. Методи. Аналіз науково-методичної літератури, синтез та узагальнення. Результати.

Внаслідок перебування в умовах інтенсивної терапії пацієнти отримують значні порушення на рівні всіх систем організму. У ході аналізу науково-методичних статей було виявлено основні порушення систем організму пацієнтів інтенсивної терапії. Доведено позитивний вплив фізичної терапії на попередження виникнення та зменшення порушень функцій дихання, нейротрофічних та метаболічних порушень, серцево-судинних уражень, а також суглобово-м'язових контрактур. Однак фізична терапія в умовах анестезіології та інтенсивної терапії має багато суперечливих методів та малу доказовість внаслідок незначної кількості досліджень. Фізична терапія значно зменшує можливість виникнення порушень і навіть попереджає їх виникнення за умови обов'язкового дотримання принципів втручання.

Ключові слова: відділення анестезіології, інтенсивна терапія, вертикалізація, мобілізація, критично хворі пацієнти, фізична терапія, принципи фізичної терапії.

\section{Basic principles of physical therapy in the conditions of anestesiology and intensive care unit}

Yu. I. Yarosh, M. Ya. Romanishyn

National University of Physical Education and Sport of Ukraine, Kyiv, Ukraine

Abstract. Today it is important to study the use of physical therapy in the Department of Anesthesiology and Intensive Care. Objective. Formulate the principles of physical therapy, which determine the methods of influencing the patient's condition in relation to his disorders. Methods. Analysis of scientific and methodological literature, synthesis and generalization. Results. As a result of being in intensive care, patients experience significant disorders at the level of all body systems. During the analysis of scientific and methodical articles the basic disturbances of systems of the body of patients of intensive care were revealed. The positive effect of physical therapy on the prevention and reduction of respiratory disorders, neurotrophic and metabolic disorders, cardiovascular lesions, and joint and muscle contractures has been proven. However, physical therapy in anesthesiology and intensive care unit has many controversial methods, and little evidence due to the small number of studies. Physical therapy significantly reduces the possibility of disorders and even prevents them in general, provided that the principles of intervention are mandatory.

Keywords: anesthesiology department, intensive care, verticalization, mobilization, critically ill patients, physical therapy, principles of physical therapy. 
Постановка проблеми. Кількість звернень за швидкою медичною допомогою становить 8059161 особа за 2019 р., а кількість осіб, доставлених бригадами швидкої медичної допомоги для госпіталізації, - 2065585 за 2019 р. (Центр медичної статистики МОЗ України, 2019 р.). Хворі, які тривалий час перебувають у критичному стані, що загрожує життю, часто зазнають фрізичних та психологічних ускладнень, перебувають на тривалій штучній вентиляції легень (ШВЛ), і в результаті $25 \%$ мають значну м'язову слабкість, а приблизно 90 \% довготермінових хворих матимуть постійну м'язову слабкість. Тому тривале перебування у відділенні інтенсивної терапії також пов'язане з погіршенням якості життя, зниженням функціональності та збільшенням захворюваності, смертності, вартості допомоги і тривалості перебування в лікарні (Chartered Society of Physiotherapy, Physiotherapy works: critical care. Accessed on 2/6/19).

Невідкладна допомога - спеціалізована допомога пацієнтам, стан яких загрожує їх життю, яким потрібні комплексна медична допомога та постійний моніторинг життєдіяльності організму у відділеннях інтенсивної терапії. Саме тому невідкладні пацієнти потребують мультидисциплінарної команди з невідкладної допомоги, яка має унікальну кваліфікацію, вміння та знання для роботи з оцінюванням і управлінням респіраторними ускладненнями, атрофічними процесами, нервово-м'язовими та опорно-руховими захворюваннями.

Дослідження проводили з хворими у важкому стані, що загрожує їх життю. Це різні хворі за своєю етіологією. Усі пацієнти мали нестабільні показники щодо гемеостазу організму. Внаслідок виникнення важких патологій або травм виникають нестабільність артеріального тиску, серцевих скорочень та функцій дихання, підвищена температура тіла і відсутність свідомості, що призводять до зміни гемеостазу організму, внаслідок чого виникає стан загрози життю пацієнта. Такий важкий стан виникає у всіх випадках патологій різного ґенезу: кардіологічного, пульмонологічного, гастроентерологічного, неврологічного, політравматологічного та загальнотравматичного.

Фізична терапія як частина мультидисциплінарного підходу до догляду $є$ невід'ємною частиною сприяння функціонуванню легенів, зменшенню захворюваності на пневмонію, пов'язану 3 вентиляцією легень, полегшенню відновлення функціональності та сприянню безпечної і ранньої виписки з відділення інтенсивної терапії. Дихальні фрізіотерапевтичні втручання можуть включати позиціонування, навчання, відлучен- ня від ШВЛ, неінвазивну вентиляцію, перкусію, зміцнення дихальних м'язів, дихальні вправи та насамперед мобілізацію. Існують суттєві докази, які підтверджують роль фрізіотерапії щодо управління дихальними шляхами критично хворих пацієнтів, яка, як було показано, надає як короткочасну, так і середньострокову користь.

Результати перехресного дослідження пацієнтів, які отримували інтенсивну фрізіотерапію грудної клітки після легеневої лобектомії, показали, що скорочення тривалості перебування в лікарні (середній термін перебування в лікарні зменшився з 8,3 до 5,7 дня) було визнано безпосередньо пов'язаним 3 фрізіотерапевтичним втручанням. Подальші результати свідчать про зниження рівня смертності, пневмонії та колапсу легенів. Рання мобілізація може скоротити тривалість перебування у лікарні. Дослідження, яке впровадило протокол ранньої мобільності, показало зменшення інтенсивної терапії та тривалості перебування в лікарні (11,2 порівняно з 14,5 дня) і потенційну економію 7 \% від стандартних витрат на догляд за пацієнтами (Tomasi CD, Figueiredo F, Constantino L, Grandi R, Topanotti MFL, Giombelli V et al., 2010). Потенційні заощадження від ранньої фрізіотерапії для важкохворих пацієнтів $\epsilon$ вагомими для економіки охорони здоров'я.

Фізична терапія має нестабільні результати досліджень щодо впливу на тривалість перебування пацієнтів на ШВЛ і у відділенні інтенсивної терапії. Як зазначають P. Waldauf et al. [17], peзультати були значимі лише для підгрупи під протоколом фрізичної терапії і поліпшувалися у пацієнтів з більш тривалим перебуванням у відділенні інтенсивної терапії та більш низькими показниками гострої фрізіології і хронічної оцінки стану здоров'я. Ранній початок втручання не показав значної користі. Можливо, кількість та методика впливу в багатьох рандомізованих контрольованих випробуваннях були меншими, ніж сказано у протоколі, і негативні результати можуть відображати нездатність реалізувати втручання. Таким чином, можна говорити, що реабілітаційні втручання у тяжкохворих пацієнтів не впливають на смертність i $\epsilon$ безпечними. Протоколи фрізичної терапії дають можливість скоротити час, що витрачається на ШВЛ і у відділенні інтенсивної терапії, але це не завжди приводить до довгострокових фуннкціональних переваг. Стабільні пацієнти з більш низьким рівнем гострої фрізіології та оцінки хронічного здоров'я під час надходження до відділення анестезіології й інтенсивної терапії (BAIT) можуть отримати найбільшу користь від реабілітаційних втручань $[17,18]$. 
Результати досліджень C. J. Tipping et al. [16] вказують на незначні результати фізичної терапії пацієнтів з критичним станом. Було проаналізовано 14 досліджень різної якості, в яких взяли участь 1753 пацієнти. Активна мобілізація і реабілітація не вплинули на смертність у відділеннях BAIT. Також метааналіз показав, що активна мобілізація і реабілітація привели до збільшення м'язової сили під час виписки з відділень інтенсивної терапії. Фізична терапія надає велику ймовірність функціональної ходьби без сторонньої допомоги при виписці з лікарні і протягом більш тривалого періоду життя поза лікарнею до 180 днів. Не було виявлено стійких впливів на функцію, якість життя, тривалість перебування у відділенні інтенсивної терапії або лікарні, тривалість ШВЛ або час виписки. Таким чином, можна стверджувати що активна мобілізація і реабілітація у відділенні інтенсивної терапії не впливають на смертність, але можуть поліпшити стан рухливості, м'язову силу і життя поза лікарнею до 180 днів.

Автори досліджень Annals of the American Thoracic Society стверджують, що мобілізація пацієнтів і фрізична терапія у відділенні інтенсивної терапії $\epsilon$ безпечними, з низькою частотою потенційних негативних впливів і тільки з рідкісними варіантами розвитку подій, що мають будь-які негативні наслідки для ведення пацієнтів. Неоднорідність визначення подій безпеки в різних дослідженнях підкреслює важливість реалізації існуючих визначень, заснованих на консенсусі, та подальше вивчення питань та методів фрізичної терапії у BAIT [12].

Однією 3 найбільш поширених проблем у процесі реабілітаційних заходів $\epsilon$ іммобілізаційний синдром (IC). Частота його розвитку у пацієнтів 3 гострою церебральною недостатністю сягає 65-80\%, а у пацієнтів відділень реанімації 3 тривалістю перебування більше 48 год - 55$98 \%$. Цим пояснюються актуальність проблеми і пріоритетність методичного забезпечення заходів щодо боротьби з ним. IC - комплекс поліорганних порушень, пов'язаних з нефізіологічними обмеженнями рухової і когнітивної активності хворого [2].

Причини IC:

- гостра церебральна недостатність (інсульт, черепно-мозкова і спинномозкова травми, інфрекції та інтоксикації ЦНС і т.д.);

- гостре ураження периферичної нервової системи (полірадікулонейропатія);

- ускладнення медичних впливів (постільний режим, седація, міорелаксація, ШВЛ і т.д.);

- клінічне розуміння IC, засноване на уявленні про розвиток поліорганних симптомокомплексів;
- м'язово-скелетні порушення (зниження синтезу м'язового протеїну);

- м'язова атрофрія, зниження м'язової сили і толерантності до навантажень, вкорочення зв'язкового апарату, м'язові контрактури, зниження щільності кісткової тканини, пролежні);

- респіраторні порушення (ателектазування, пневмонія, зниження максимального тиску вдиху і фрормування життєвої ємності легень);

- ендокринно-метаболічні порушення (зниження чутливості до інсуліну, активності ренінангіотензинової системи);

- збільшення вироблення натрійуретичного пептиду;

- кардіоваскулярні порушення (зменшення розміру серця, ємності венозних судин нижніх кінцівок; зниження ударного об'єму серця і периферичного опору, чутливості каротидного синуса).

Сукупність наведених симптомокомплексів, зокрема кардіоваскулярних, призводить до фрормування ортостатичної недостатності $[1,2]$.

Мета дослідження - виділити основні порушення стану пацієнтів в умовах BAIT, визначити ефективні методи впливу щодо відновлення функціонального стану хворих, сфрормулювати принципи фрізичної терапії, які визначають методи впливу на стан пацієнта відносно його порушень.

Методи дослідження: аналіз науково-методичної літератури, синтез та узагальнення.

Результати дослідження. Безпека та доцільність ранньої фрізичної терапії в умовах BAIT $\epsilon$ значною частиною лікувального процесу хворих. 3 огляду на зростаючу кількість літератури про слабкість, набуту в реанімаційному відділенні, та шкоду постільного режиму, рання мобілізація та реабілітація важкохворих привертають увагу. Незважаючи на потенційне занепокоєння щодо мобілізації пацієнтів з механічною вентиляцією, багато досліджень неодноразово демонстрували її безпеку та доцільність. У німецькому національному дослідженні точкової поширеності у 775 суб'єктів з механічною вентиляцією частота потенційних подій безпеки не була вищою при позаліжковій та протиліжковій діяльності. При мобілізації пацієнтів з механічною вентиляцією найбільш частими потенційними подіями $\epsilon$ фізіологічні зміни, які $\epsilon$ тимчасовими і вирішуються після відпочинку, без будь-якого втручання.

У сучасному критичному догляді за пацієнтами у важкому стані постільний режим $€$ звичайною практикою, особливо для пацієнтів 3 механічною вентиляцією, де частіше розпізна- 
ються короткочасні та довгострокові негативні наслідки. Рання мобілізація та реабілітація $€$ безпечними і здійсненними, маючи деякі дані про покращення результатів пацієнта, включаючи зменшення тривалості ШВЛ та поліпшення фрізичного фрункціонування.

Структуровані проєкти підвищення якості $\epsilon$ вирішальними для подолання великого розриву між цими результатами досліджень та рутинною клінічною практикою, щоб пришвидшити відновлення після BAIT пацієнтів з механічною вентиляцією. Залучення мультидисциплінарної команди з визнаним лідером може ефективно впливати на зміну культури та практики реанімації для ефективної ранньої мобілізації і реабілітації.

Під час вибору методу втручання у фрізичній терапії пацієнтів BAIT важливо враховувати принцип раннього початку, адже чим раніше відбудеться мобілізація пацієнта, тим більше у нього шансів відновити свої рухові функції. Поступова вертикалізація має позитивний вплив на загальний стан організму, адже при перебуванні у вертикальному положенні відбувається правильний розподіл тиску на периферійні судини та включаються в роботу екстракардіальні фрактори серцево-судинної системи, що $є$ профрілактикою іiї захворювань та тромбоутворень.

Якщо основне та супутні порушення стану пацієнта BAIT не є протипоказаннями до вертикалізації і мобілізації, слід розпочинати фрізичну терапію. Як тільки пацієнт є стабільним, варто починати з поступової вертикалізації під пильним контролем пульсу, сатурації, артеріального тиску та температури тіла. Проводити фрізичну терапію не можна у випадку, якщо:

- температура тіла $\geq 38-38,5{ }^{\circ} \mathrm{C}$;

- артеріальний тиск систолічний $\leq 100$ та $>200$;

- сатурація кисню у крові $<92 \%$.

У разі відсутності протипоказань і вищенаведених обмежуючих показників можна якнайшвидше починати вертикалізацію, мобілізацію і згодом, по можливості, відновлення основних фрункцій життєдіяльності.

Значення щодо вертикалізації є основним показником, що вказує на доцільність та прогнозованість впливу фрізичної терапії в умовах ВАІT. Гравітаційний градієнт - здатність підтримувати стабільні вітальні параметри у будь-якому положенні тіла відносно гравітаційного поля Землі, що забезпечується складним рефрлекторним стереотипом. Сутність стереотипу у тому, що у відповідь на аферентну стимуляцію стовбура мозку від рецепторів півколових каналів і пресорецепторів стопи підвищується тонус ємнісних судин, розташованих нижче діафрагми, тонус периферійних артерій і знижується тонус мозкових артерій. У результаті відбуваються внутрішня «централізація кровообігу» і збільшення середнього артеріального тиску. У поєднанні зі зниженим опором церебральних судин це забезпечує збереження нормального церебрального перфузійного тиску в момент підйому пацієнта і відсутність будь-яких ортостатичних негативних реакцій, що призводять до загального погіршення стану та симптоматики хворого.

Єдиним способом подолання IC з розумінням поняття збереження гравітаційного градієнта $€$ вертикалізація пацієнта. Вертикалізація $€$ лікувальною стратегією забезпечення нормального функціонування організму в природному вертикальному положенні, методом профілактики і лікування IC у хворих будь-якого профрілю [14-16].

Мета вертикалізації - підтримання або відновлення максимального значення гравітаційного градієнта як обов'язкової умови функціонування пацієнта в ході реабілітаційного процесу. Вона досягається в ході ортостатичних тренувань, що забезпечують збереження (відновлення) адекватної аферентації від суглобових і м'язовосухожильних рецепторів при замиканні суглобів нижніх кінцівок і хребта, збереження належного впливу на познотонічну і динамічну активність вестибулярних та постуральних реслекторних реакцій і автоматизмів. У такому випадку відзначається також поліпшення респіраторної функції, збереження рефлекторного механізму випорожнення кишечнику і сечового міхура.

Невід'ємною частиною фрізичної терапії та загального медичного лікування у BAIT $\epsilon$ оцінювання та регуляція больового стану пацієнта. Оцінювання болю у важкохворих пацієнтів 3 механічною вентиляцією $є$ великою проблемою. Існує потреба в адекватному засобі вимірювання болю у свідомих пацієнтів, але які перебувають під впливом седативних препаратів, через їх сумнівні комунікативні можливості. Автори Ahlers, Sabine J. G. M. MSc et al. оцінюють використання шкали поведінкового болю (Behavioral Pain Scale - BPS) у пацієнтів зі свідомим седативним станом порівняно з її використанням у глибокоседативних пацієнтів, для яких ця шкала була розроблена. Було включено 15 досліджень, які показали, що поведінкова шкала болю як інструмент спостереження за болем критичної допомоги $є$ дійсною та надійною. Вона надійна в оротрахеально інтубованих пацієнтів, які потрапляють у відділення інтенсивної терапії. Метааналіз вказує на достовірні психометричні властивості та хорошу надійність [5-11]. 
Крім вертикалізації, важливою частиною процесу фрізичної терапії $€$ порушення фрункції дихання. Протягом перших нерухомих 48 год відзначено появу рентгенологічних ознак часткового або повного ателектазування нижньої частки лівої легені. Це пов'язують з краніальним зміщенням діафрагми в положенні на спині та гравітаційним зміщенням серця назад. Поява ателектаз в інших ділянках, верифрікованих при КТ-дослідженнях, пов'язана зі зниженням легеневого комплексу при положенні на спині. Пов'язаний з цим сценарій респіраторних ускладнень добре відомий: зниження аерації в зонах ателектазування, підвищення резистентності легеневих судин, внутрішньолегеневе шунтування з підвищенням кисневої залежності, вентиляційне ушкодження легень. Таким чином, перебування в ліжку сприяє розвитку первинних респіраторних проблем і їх прогресуванню у пацієнтів з безпосереднім ушкодженням легень у структурі критичного стану [13]. Задля покращення функцій дихання та зменшення ускладнень фрізична терапія має містити вправи на розтягнення і скорочення дихальних м'язів. Вправи мають бути як пасивними, так і активними, залежно від стану свідомості пацієнта.

Під час перебування у BAIT пацієнти також отримують метаболічні ускладнення, що призводять до важких наслідків. Інсулінова резистентність - часте явище у пацієнтів у критичному стані без діабету в анамнезі. Вплив постільного режиму на розвиток цього стану було оцінено в експерименті з 20 здоровими добровольцями, поміщеними на п'ять днів в умови суворого постільного режиму з 30-хвилинними паузами для гігієни. При незмінній вазі рівень глікемії після введення розчинів глюкози і концентрація інсуліну виявилися достовірно вище їх вихідного рівня, залишаючись підвищеними деякий час після припинення постільного режиму. Крім того, відзначено підвищення рівнів загального холестерину і тригліцеридів [3]. Мобілізація пацієнтів пасивно чи активно впливатиме на зменшення впливу постільного режиму та, як наслідок, зменшення можливості розвитку інсулінової резистентності.

Серцево-судинні порушення супроводжують проблематику лікування реанімаційних пацієнтів. Різні матеріали досліджень вказують, що при перебуванні на постільному режимі відбувається зниження ударного обсягу і прогресування тахікардії на один удар кожні два дні, зниження екстракції $\mathrm{O}_{2}$ на $27 \%$ за 20 днів, який поєднується 3 повільно прогресуючою до 2-4-го тижня анемією. Все це сприяє зниженню толерантності до навантаження. Цей фракт відзначений клінічно майже у всіх пацієнтів з тривалістю постіль- ного режиму більше 5-7 днів. 3 іммобілізацією пов'язують також дисфункцію системного судинного ендотелію як фрактора атерогенезу. Поступова вертикалізація та мобілізація пацієнтів сприяють нормалізації кровообігу і підтриманню нормального тиску в судинах тіла.

Внаслідок постійного медикаментозного лікування та атонії м'язів виникають тромбоемболічні порушення. Ґрунтуючись на тріаді Вирхова фракторів тромбоемболічної хвороби, з режимом «перебуваючи в ліжку» пов'язаний основний із них - зниження об'ємного кровотоку до кінцівки, обумовлене зниженням іï̈ функціональної активності. Уповільнення кровотоку, вторинна компресія в точці контакту з постіллю і гіпертонічність м'язів (при гострій церебральній недостатності) - все це сприяє венозному стазису й ушкодженню судинного ендотелію. Таким чином, перебування в ліжку сприяє підвищенню ризиків тромбоемболічного синдрому і прогресуванню венозної клапанної недостатності як однієї з причин ортостатичної недостатності.

Тривале перебування у важкому стані та постійно знерухомленому лежачому положенні призводить до суглобових ушкоджень [4]. Суглоби, обмежені при перебуванні в ліжку в обсязі фрізіологічної активності в поєднанні з полінейроміопатією, фрормують контрактури. До моменту переведення з BAIT до $34 \%$ пацієнтів мають принаймні одну функціонально значущу контрактуру, а у $23 \%$ вона зберігається на момент остаточної виписки зі стаціонару. Найчастіше до цього схильні плечовий (34 \%) і ліктьовий (33 \%) суглоби. Важливим фрактором $€$ неконтрольований больовий синдром при сублюксації плечового суглоба у пацієнтів $з$ парезами верхніх кінцівок. Активна профрілактика ведеться практично у всіх BAIT у вигляді пасивної фрізичної терапії, позиціонування й ортезування. Там, де це організовано як системний захід, частота ускладнень знижується.

Однією з найчастіших проблем пацієнтів BAIT $\epsilon$ нейротрофрічні порушення. Пролежні утворюються через постійний тиск у точках контакту з поверхнею ліжка. Найбільш високий тиск створюється в ділянці крижової зони за рахунок додаткового навантаження при піднятому головному кінці. У пацієнтів з надлишковою масою тіла тиск на рівень контакту з поверхнею ліжка в поперековій ділянці сягає 32 мм рт. ст. і може призвести до появи пролежнів протягом 2 год. Крім зазначених вище порушень мікроциркуляції, утворенню пролежнів сприяють гіповолемія і нутрітивний дефіцит. Пролежні відкривають ворота для патогенних агентів, що призводить до целюліту й остеомієліту в прилеглих ділянках. 
Нозологічною фрормою ураження нейром'язової системи при іммобілізації $€$ поліміонейропатія критичних станів (ПМКС) [1, 2]. ПМКС набутий внаслідок критичного стану синдром нервово-м'язових порушень за типом полінейропатії і/або міопатії, що клінічно проявляється загальною м'язовою слабкістю і $€$ основною причиною труднощів у припиненні ШВЛ. В окремих джерелах можна знайти іншу назву цього синдрому - синдром хронічної у BAIT слабкості (ICUAW).

На відміну від інших станів, здатних викликати клініку нейром'язової слабкості у пацієнтів у BAIT, ПМКС $є$ винятковим проявом ПІТ-синдрому, зокрема ускладненням режиму перебування в ліжку за механізмом learned non-use, а також наслідком метаболічних, водно-електролітних порушень, поліорганної недостатності, нестачі нутрієнтів і, нарешті, побічним ефектом неминуче використовуваних нейротоксичних лікарських препаратів (кортикостероїдів, антибіотиків, міорелаксантів та ін.).

Дискусія. Поглиблене вивчення проблеми виявило стовідсоткову частоту розвитку поліміонейропатії критичних станів у іммобілізованих пацієнтів нейрореанімаційного профрілю протягом 24-48 год. [1, 2]. Незалежно від нозології 25-33\% пацієнтів через сім днів ШВЛ набувають ознак нейром'язової недостатності. У більшості досліджень показано пряму кореляцію між тривалістю ШВЛ, тривалістю перебування у ВАІT і ступенем вираженості ПМКС.

Враховуючи вищенаведені проблеми перебування у BAIT, можна сорормулювати принципи впливу фрізичної терапії на пацієнтів:

1. Комплексний вплив фрізичної терапії

Перебуваючи у важкому стані, пацієнти потребують комплексного підходу до поступової мобілізації та вертикалізації. Виконуючи лише вертикалізацію, неможливо досягнути правильного результату, не використовуючи мобілізацію опорно-рухового апарату та дихальних м'язів.

\section{Література}

1. Белкин АА, Авдюнина ИА, Варако НА и др. Реабилитация в интенсивной терапии [Rehabilitation in an intensive therapy]. Методические рекомендации, 2015.

2. Белкин АА, Давыдова НС, Лейдерман ИН и др. Реабилитация в интенсивной терапии. Клинические рекомендации. Анестезиология и реаниматология. [Reabilitatsiya v intensivnoy terapii. Klinicheskie rekomendatsii. Anesteziologiya i reanimatologiya]. Под ред. ИБ Заболотских и ЕМ Шифмана. Москва: ГЭОТАР-медиа, 2016:833-58.

3. Губайдуллин РР, Гусакова ЕВ, Черемисов ВВ, Рымарчук РА, Кулаков ВB, Черепанова ОН. Периоперационная реабилитация: eras или профилактика PICS? [Perioperative rehabilitation: eras or PICS prevention?].
2. Послідовність методів фрізичної терапії

Поєднання методів вирішення багатьох проблем, таких як порушення дихання, трофрічні порушення, нейром'язова слабкість, порушення нормального тонусу судин та інших, виконує фрункцію комплексності впливу. Тобто вертикалізація не може бути проведена без попередньої доцільної мобілізації та покращення дихальної фрункції.

3. Доцільність впливу фрізичної терапії

Пацієнти у важкому стані, які перебувають в умовах BAIT, не завжди швидко стабілізуються з точки зору фрізіології. Тому важливо розуміти, чи варто взагалі вертикалізувати пацієнта, якщо, наприклад, він не має толерантності до вертикалізації та вертикалізаційний градієнт на критично низькому рівні. Важливо враховувати основні фрізіологічні показники стану пацієнта, перш ніж використовувати методи фрізичної терапії.

Висновки. Загальний аналіз даних сучасної літератури показав, що фрізична терапія в умовах анестезіології та інтенсивної терапії має багато суперечливих методів та малу доказовість внаслідок незначної кількості досліджень. Тому вивчення питання фрізичної терапії в умовах BAIT важливе у подальшому розвитку галузі критичної медицини. Програма якісного та ефективного відновлення в умовах BAIT має значення як для пацієнта, так і для розвитку галузі в цілому.

Сорормульовані принципи фрізичної терапії в умовах BAIT дають можливість краще розуміти складність та багатовимірність фрізичної терапії критичних хворих. Спираючись на такі принципи, можна прогнозувати та складати план фрізіотерапевтичного втручання, а також проводити оцінювання стану пацієнта. Використання цих принципів у фрізичній терапії важкохворих попереджує виникнення набутих патологій під час перебування у BAIT, прискорює реконвалесценцію та сприяє й адаптує до швидкого початку самообслуговування, а також надає можливість доречно використовувати методи фрізичної терапії для важкохворих з метою покращення їх загального стану та прискорення одужання.

URL: https://cyberle-ninka.ru/article/n/perioperatsionnaya-reabilitatsiya-eras-ili-profilaktika-pics (дата обращения: 20.06.2021).

4. Оганов РГ, Денисов ИН, Симаненков ВИ и др. Коморбидная патология в клинической практике. Клинические рекомендации. Кардиоваскулярная терапия и профилактика. [Comorbidities in practice. Clinical guidelines. Cardiovascular Therapy and Prevention]. 2017;16(6):5-56. DOI: 10.15829/1728-8800-2017-6-5-56

5. Ahlers, Sabine JGM. MSc; van der Veen, Aletta M. MScN; van Dijk, Monique PhD et al. The Use of the Behavioral Pain Scale to Assess Pain in Conscious Sedated Patients Anesthesia \& Analgesia: January 2010;110(1): 127-33. 


\section{Спортивна медицина, фізична терапія та ерготерапія № 2, 2021}

6. Arbour C, Gélinas C, Michaud C. Impact of the implementation of the Critical-Care Pain Observation Tool (CPOT) on pain management and clinical outcomes in mechanically ventilated trauma intensive care unit patients: a pilot study. J Trauma Nurs. 2011;18(1):52-60.

7. Bottega FH, Fontana RT. A dor como quinto sinal vital: utilização da escala de avaliação por enfermeiros de um hospital geral. Texto Contexto Enferm. 2010;19(2):283-90.

8. Chanques G, Jaber S, Barbotte E, Violet S, Sebbane M, Perrigault PF et al. Impact of systematic evaluation of pain and agitation in an intensive care unit. Crit Care Med 2006;34:1691-9.

9. Frandsen JB, O'Reilly Poulsen KS, Laerkner E, Stroem T. Validation of the Danish version of the Critical Care Pain Observation Tool. Acta Anaesthesiol Scand. 2016;60(9):1314-22.

10. Miner JR, Krauss B. Procedural sedation and analgesia research: state of the art. Acad Emerg Med 2007;14:170-8.

11. Nascimento JC, Silva LC. Avaliação da dor em pacientes sob cuidados em unidades de terapia intensiva: uma revisão de literatura. Rev Movimenta. 2014;7(2):711-20.

12. Nydahl P, Sricharoenchai T, Chandra S, Kundt FS, Huang M, Fischill M, Needham DM. Safety of patient mobilization and rehabilitation in

juliyyarosh@gmail.com the intensive care unit: systematic review with meta-analysis Annals of the American Thoracic Society 2017 May;14(5):766-77.

13. Rittayamai N, Wilcox E, Drouot $X$, et al. Positive and negative effects of mechanical ventilation on sleep in the ICU: a review with clinical recommendations. Intensive Care Med. 2016;42(4):531-41.

14. Schaller S, Anstey M, Blobner M et al. Early, goal-directed mobilisation in the surgical intensive care unit: a randomised controlled trial. The Lancet. 2016;388(10 052):1377-88. DOI: 10.1016/s0140-6736(16)31637-3

15. Tipping CJ, Harrold M, Holland A et al. The effects of active mobilisation and rehabilitation in ICU on mortality and function: a systematic review. Intensive Care Medicine. 2016;43(2):171-83. DOI: 10.1007/s00134-016-4612-0

16. Tipping CJ, Harrold M, Holland A, Romero L, Nisbet T, Hodgson CL. The effects of active mobilisation and rehabilitation in ICU on mortality and function: a systematic review. Intensive Care Med. 2017;43(2):171-83.

17. Waldauf $P$, Jiroutkova K, Krajcova A, Puthucheary Z, Duska F. Effects of rehabilitation interventions on clinical outcomes in critically ill patients: systematic review and meta-analysis of randomized controlled trials Critical Care Medicine $2020 \mathrm{Jul} ; 48(7): 1055-65$.

18. Zhang J, Zhao X, Wang A. Early rehabilitation to prevent postintensive care syndrome in critical illness patients: Zhongguo Wei Zhong Bing Ji Jiu Yi Xue [Chinese Critical Care Medicine] 2019 Aug;31(8):1008-12. 